\title{
KANDUNGAN FENOL PADA PINEKUHE YANG DIOLAH DENGAN ASAP CAIR DAN PENGASAPAN KONVENSIONAL
}

\section{Phenol Contents of Pinekuhe Processed by Liquid Smoking and Conventional}

\author{
Jefri Antonius Mandeno"), Mukhlis Abdul Kaim² \\ ${ }^{1}$ Program Studi Teknologi Pengolahan Hasil Laut POLNUSTAR \\ ${ }^{2}$ Program Studi Teknologi Penangkapan Ikan POLNUSTAR \\ E-mail: jefri.mandeno76@gmail.com
}

\begin{abstract}
Abstrak : Tujuan dari penelitian ini adalah untuk mengetahui kandungan fenol pada ikan asap pinekuhe dengan asap cair dan dengan pengasapan konvensional. Penelitian menggunakan Rancangan deskriptif kualitatif dengan memberikan gambaran proses dan hasil penelitian melalui gambar, tabel maupun histogram. Perlakuan dalam penelitian adalah sebagai berikut: (A) Ikan asap pinekuhe ang direndam dalam asap cair lalu dikeringkan, (B) Ikan asap pinekuhe yang dkeringkan, direndam dalam asap cair lalu dikeringkan, (C) Ikan asap pinekuhe direndam dalam asap cair lalu dikeringkan dan (D) Ikan asap pinekuhe dari pengasapan konvensional dengan bahan bakar biasa. Kesimpulan dari hasil penelitian ini bahwa ikan asap cair yang dikeringkan kemudian direndam dalam asap cair memiliki kadar fenol yang lebih tinggi jika dibandingkan dengan ikan asap yang diolah dengan metode pengasapan konvensional, yaitu dengan menggunakan bahan bakar cangkang pala. Kadar fenol tertinggi yaitu pada perlakuan B $(15,77 \%)$ dan kadar fenol terendah yaitu pada perlakuan C $(10,2 \%)$.
\end{abstract}

Kata Kunci : pengasapan, pinekuhe, fenol, Sangihe

Abstract: The purpose of this study was to determine the phenol content of pinekuhe smoked fish with liquid smoke and conventional smoking. The study used a qualitative descriptive design by providing an overview of the research process and results through pictures, tables, and histograms. The treatments in the study were as follows: (A) Pinekuhe smoked fish soaked in liquid smoke then dried, (B) Pinekuhe smoked fish that was dried, soaked in liquid smoke then dried, (C) Pinekuhe smoked fish was immersed in liquid smoke then dried and (D) Pinekuhe smoked fish from conventional smoking on ordinary fuel. The conclusion from the results of this study is that smoked fish that is dried and then immersed in liquid smoke has a higher phenol content when compared to smoked fish processed by conventional smoking methods, namely using nutmeg shell fuel. The highest phenol content was in treatment B $(15.77 \%)$ and the lowest phenol content was in treatment $C(10.2 \%)$ Abstract: The purpose of this study was to determine the phenol content of pinekuhe smoked fish with liquid smoke and conventional smoking. . The study used a qualitative descriptive design by providing an overview of the research process and results through pictures, tables, and histograms. The treatments in the study were as follows: (A) Pinekuhe smoked fish soaked in liquid smoke then dried, (B) Pinekuhe smoked fish that was dried, soaked in liquid smoke then dried, (C) Pinekuhe smoked fish was immersed in liquid smoke then dried and (D) Pinekuhe smoked fish from conventional smoking on ordinary fuel. The conclusion from the results of this study is that smoked fish that is dried and then immersed in liquid smoke has a higher phenol content when compared to smoked fish processed by conventional smoking methods, namely using nutmeg shell fuel. The highest phenol content was in treatment B $(15.77 \%)$ and the lowest phenol content was in treatment C (10.2\%).

Keyword: smoking, pinekuhe, phenol, Sangihe 


\section{PENDAHULUAN}

Ikan asap pinekuhe adalah ikan asap yang memiliki bentuk yang unik dan memiliki ciri khas ikan asap yang sangat tradisional. Ikan Asap pinekuhe hanya terdapat $\mathrm{di}$ daerah Kepulauan Sangihe dan pada umumnya diolah secara tradisional. Ikan asap pinekuhe banyak di gemari bagi para konsumen yang ada di Sangihe maupun di luar Sangihe. Umumnya produk pinekuhe ini tidak menggunakan kemasan, dan dipasarkan dengan hanya dipajang di wadah penjualan di udara terbuka (Mandeno $d k k, 2014$ dan Mandeno $d k k, 2006)$. Selain itu, pinekuhe yang dihasilkan memiliki masa simpan yang relative singkat tergantung kesegaran ikan (Palawe $d k k, 2016$ ) dan suhu pengasapan yang digunakan. Proses pengasapan pinekuhe di masyarakat masih bersifat konvensional dengan bahan bakar yang sangat tergantung pada ketersediaan di lingkungan sekitar seperti kayu, batang, tempurung dan pelepah daun kelapa (Tirajoh, 1995). Oleh karena itu mutu mikrobiologis dari ikan asap pinekuhe masing tergolong kurang baik (Palawe $d k k, 2014)$. Menurut Berhimpon, $d k k$ (2019) dan Mandeno $d k k$, 2018, bahwa kualitas asap juga ditentukan oleh senyawa-senyawa karbon yang terkandung dalam bahan bakar. Tempurung dan kayu keras akan memberikan asap yang lebih baik karena kandungan lignin dalam tempurung dan kayu keras lebih banyak. Pengasapan ikan juga dapat dilakukan dengan metode pengasapan cair (Utomo $d k k$, 2012). Metode pengasapan cair dilakukan dengan menggunakan asap cair yang merupakan hasil dari kondensasi asap dari hail pembakaran kayu (Setiaji, 2006). Asap cair mengandung senyawa fenol, asam organik dan karbonil. Senyawa-senyawa tersebut dapat berperan sebagai anti mikroba dan penambahan senyawa anti mikroba dari alam juga sering ditambahakan untuk memperpanjang masa simpan (Palawe $d k k, 2018$ ).
Reaksi Maillard antara gugus karbonil dan protein menghasilkan karakteristik ikan asap pada kenampakan, tekstur dan warna (Varlet et al, 2007., Pagoray 2004). Tujuan dari penelitian ini yaitu untuk mengetahui kandungan fenol pada ikan asap pinekuhe dengan asap cair dan dengan pengasapan konvensional.

\section{METODE PENELITIAN}

Penelitian ini akan dilakukan di dua lokasi yakni di Kabupaten Kepulauan Sangihe yang mana untuk pengolahan ikan asap pinekuhe dan pengujian total fenol dilakukan di sedangkan pengujian kandungan fenol dilakukan di Malang. Bahan baku utama yang akan dijadikan sampel untuk penelitian ini yaitu ikan layang. Untuk pembuatan pinekuhe dan bahan bakar cangkang pala sedangkan bahan untuk pengujian fenol digunakan bahan-bahan kimia seperti aquades, alkohol, larutan bromide, indikator kanji, larutan stok fenol dan lain-lain. Alat - alat yang digunakan dalam penelitian yakni untuk pembuatan pinekuhe alat yang digunakan yaitu lemari pengasapan, pisau penyiangan, thermometer, talenan dan wadah sedangkan untuk pengujian ornganoleptik digunakan bilik organoleptik dan pengujian fenol alat yang diperlukan erlemeyer, gelas ukur, pipet, peralatan titrasi.

\section{Pembuatan Pinekuhe}

Sebagai awal dari penelitian ini adalah pembuatan ikan asap pinekuhe dengan tahapan sebagai berikut : Ikan layang (Decapterus sp) yang akan digunakan pada Penelitian ini, akan dibeli di tempat pelelangan ikan Towo Tahuna, yang mana ikan layang tersebut masih segar, dengan ukuran dan kesegaran relatif sama. Ikan Layang segar kemudian disiangi dengan cara mengeluarkan isi perut dan insangnya, kemudian ikan dibelah menjadi dua bagian dilipat dengan posisi lipatan daging ikan 
di bagian luar dan kulit ikan di bagian dalam. Dengan cara menusukan ekor ikan pada bagian operculum dari ikan. Setelah dilipat, ikan dibersihkan dengan air bersih. Ikan yang diolah dengan cara dan bentuk seperti ini, membuat permukaan daging ikan menjadi lebih luas sehingga mempercepat proses pengasapan. Ikan yang telah dilipat dan dicuci proses selanjutnya dilakukan persiapan peralatan untuk pengasapan ikan, seperti kayu penusuk ikan dan para-para tempat pengasapan ikan. Selanjutnya ikan ditusuk dengan kayu penusuk ikan dengan posisi kepala diatas. Ditusuk dari bagian dada ikan sampai ke bagian sirip anal dari ikan. Kemudian ikan dimasukan kedalam tempat pengasapan diletakan secara horisontal. Apabila sudah terisi penuh maka api untuk pemanasan dinyalakan, ikan dalam tempat pengasapan tidak langsung diasapi tetapi, dilakukan pembakaran terlebih dahulu sampai bagian bawah ikan kelihatan berwarna menjadi merah, barulah ikan diasapi dengan ditutupnya bagian atas para - para agar suhu pengasapan tetap stabil dan merata. Proses pemanasan berlangsung \pm 4 jam dengan suhu $80^{\circ} \mathrm{C}$ sedangkan suhu pengasapan di ukur dengan thermometer yaitu dengan suhu $75^{\circ} \mathrm{C}$.

Bahan bakar yang digunakan adalah kayu kelapa kering. Pengasapan dengan menggunakan asap cair dilakukan dengan merendam ikan layang yang sudah dibentuk dalam larutan asap cair dengan konsentrasi asap cair 5\% selama dua jam, kemudian dikeringkan dalam oven pada suhu $80^{\circ} \mathrm{C}$ selama empat jam.

\section{Penghitungan Fenol}

Perhitungan total fenol dilakukan dengan metode sebagai berikut : Timbang contoh $3-5$ gram dan larutkan dalam $100 \mathrm{~mL}$ aquades. Pipet $10 \mathrm{~mL}$ larutan baku fenol 1000 mL 100 ppm masukkan ke dalam erlemeyer asah tertutup. Pipet larutan contoh $25 \mathrm{ml}$ ke dalam dan masukkan ke dalam erlemeyer asah tertutup. Tambahkan tetes demi tetes (menggunakan pipet) $10 \mathrm{~mL}$. Larutkan bromatbromite $0,1 \mathrm{~N}$. Segera tambahkan $5 \mathrm{~mL} \mathrm{HCl} 1: 1$, tutup kemudian kocok perlahan - lahan. Jika warna coklat dari bromide bebas tidak tampak, tambahkan $10 \mathrm{~mL}$ larutan bromat bromide hingga tampak coklat. Diamkan 10 menit, kemudian tambahkan kira - kira 1 gr KI. Titrasi dengan sodium thio sulfat 0,025 N, menggunakan indikator kanji. Titrasi dihentikan sesaat setelah warna coklat berubah menjadi warna bening. Perhitungan konsentrasi fenol dengan cara sebagai berikut :

$$
\text { Fenol }(\mathrm{mg} \%)=
$$

$\frac{\text { Blanko - titrasi x faktor pengencer x 7,842 X 100\% }}{\text { Mg Contoh }}$

\section{Rancangan Penelitian}

Penelitian menggunakan Rancangan Deskriptif kualitatif dengan memberikan gambaran proses dan hasil penelitian melalui gambar, tabel maupun histogram. Perlakuan dalam penelitian adalah sebagai berikut :

$\mathrm{A}=$ Ikan asap pinekuhe yang direndam dalam asap cair lalu dikeringkan

$\mathrm{B}=$ Ikan asap pinekuhe yang dkeringkan, direndam dalam asap cair lalu dikeringkan

$\mathrm{C}=\mathrm{Ikan}$ asap pinekuhe direndam dalam asap cair lalu dikeringkan

$\mathrm{D}=$ Ikan asap pinekuhe dari pengasapan konvensional dengan bahan bakar biasa

\section{HASIL DAN PEMBAHASAN}

\section{Kadar fenol}

Hasil pada total fenol dapat dilihat pada gambar di bawah ini. 


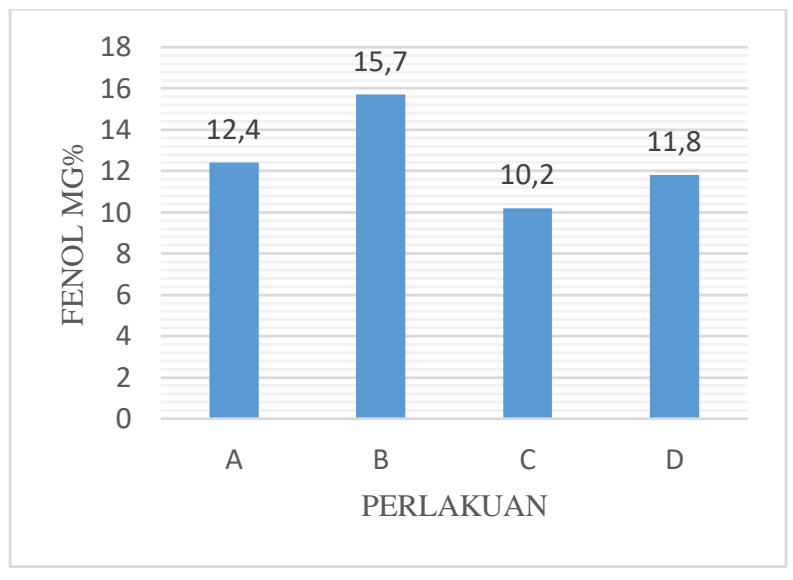

Gambar 1. Total Fenol

Data tersebut menunjukkan, kadar fenol tertinggi yaitu $15,7 \mathrm{mg} \%$ yang diperoleh dari ikan asap pinekuhe yang dikeringkan, direndam dalam asap cair lalu dikeringkan dalam oven, sedangkan kadar fenol terendah yaitu $10.2 \mathrm{mg} \%$ yang diperoleh dari ikan asap pinekuhe dari pengasapan konvensional. Tingginya kadar fenol pada ikan asap yang dikeringkan, direndam dalam asap cair lalu dikeringkan kemungkinan disebabkan karena pengeringan awal menyebabkan daging banyak kehilangan air sehingga kondisi daging menjadi mudah menyerap air. Dengan demikian saat direndam dalam cairan asap, daging ikan menyerap asap cair tersebut yang mana fenol larut di dalamnya, dalam jumlah yang banyak. Menurut Swastawati $d k k$ (2017), perbedaan jenis pengasapan dapar mempengaruhi mutu kimiawi dari ikan asap seperti kadar fenol dan kadar fenol pada ikan asap dengan menggunakan asap cair lebih rendah jika dibandinkan dengan kadar fenol pada ikan asap yang menggunakan metode pengasapan tradisional. Jumlah konsentrasi dari asap cair juga sangat berpengaruh terhadap kadar fenol dari ian asap tersebut (Ghazali $d k k$, 2014., Heller $d k k, 1980$. , Khamidah $d k k$, 2019) juga menyebutkan bahwa ikan asap yang diolah menggunakan asap cair memiliki kandungan fenol yang lebih rendah dibandingkan dengan pengasapan yang menggunakan lemari pengasapan. Mutu kimiawi dari ikan asap pinekuhe sangat mempengaruhi tingkat penerimaan dari konsumen (Palawe, 2020)

\section{KESIMPULAN}

Kesimpulan dari hasil penelitian ini bahwa ikan asap cair yang dikeringkan kemudian direndam dalam asap cair memiliki kadar fenol yang lebih tinggi jika dibandingkan dengan ikan asap yang diolah dengan metode pengasapan konvensional, yaitu dengan menggunakan bahan bakar cangkang pala. Kadar fenol tertinggi yaitu pada perlakuan B $(15,77 \%)$ dan kadar fenol terendah yaitu pada perlakuan C (10,2\%).

\section{DAFTAR PUSTAKA}

Badan Standar Nasional. 2009. SNI 2725 : 1. Syarat Mutu Ikan Asap. Jakarta

Badan Standar Nasional. 2015. SNI 2346 : Pedoman Pengujian sensori Pada Produk Perikanan. Jakarta

Berhimpon, S. 1974. Pengaruh Bahan Pengawet Kimia Dan Lama penyimpanan Terhadap Mutu Ikan Mas (Cyprinus carpio) Asap Yang Disimpan Pada Suhu Kamar, Fakultas Perikanan Universitas Sam Ratulangi Afiliasi Institut pertanian Bogor.

Berhimpon, S., Montolalu R, Dien H, Mentang A, Ticoalu R, Dien C, 2019, Katsuobushi (Ikan Kayu) Teknologi dan Peluang Bisnis, CV.Patra Media Grafindo, Bandung

Ghazali Rofi Rifki, Fronthea Swastawati, Romadhon. 2014. Analisa Tingkat Keamanan Ikan Manyung (Arius Thalassinus) Asap yang Diolah Dengan Metode Pengasapan Berbeda. Jurnal Pengolahan dan Bioteknologi Hasil Perikanan. Volume 3, Nomer 4, Tahun 2014, Halaman 31-38. 
Heller, B. 1980. Liquid Smoke Flavour Suited To Meat Products. Journal of Food Technology. (22) : 4

Khamidah Siti, Fronthea Swastawati, Romadhon. 2019. Efek Perbedaan Lama Perendaman Asap Cair Kulit Durian Terhadap Kualitas Ikan Manyung (Arius Thalassinus) Asap. Jurnal Ilmu dan Teknologi Perikanan. Volume 1 No 1. Universitas Diponegoro. Semarang

Mandeno Jefri, 2006, Pemanfaatan Asap Cair dari Tongkol Jagung (Zee mays 1) Dalam Pengolahan Julung Julung (Hemirhampus sp) Asap. Tesis, Universitas Sam Ratulangi, Manado

Mandeno, Jefri A dan Palawe, Jaka F.P. 2018, Kajian Penggunaan Asap Cair Dalam Pengolahan Pinekuhe Ikan Layang (Decapterus ruselli) Asap, Jurnal Ilmiah Tindalung Volume: 4 no.2 Halaman 71-77. Tahuna

Mandeno, Jefri A dan Muhklis A Kaim, 2015. Pengaruh Pengemasan Terhadap Mutu Pinekuhe Ikan Layang (Decapterus sp) Asap. Jurnal ilmiah Tindalung Volume 1 Nomor 1 Halaman 7-11, Tahuna

Utomo Bagus, Wibowo Singgih, Widianto Tri Nugroho. 2012. Asap Cair: Cara Membuat dan Aplikasinya pada Pengolahan Ikan Asap, Penebar Swadaya, Jakarta

Palawe, J. F.P, Wodi, S. I. M., \& Cayono, E. (2016). Analisis Kontaminasi Total Mikroba pada Beberapa Produk Ikan Segar Kabupaten Kepulauan Sangihe. Jurnal Ilmiah Tindalung, 2(1), 42-46

Palawe, J. F. P, Suwetja, I. K., \& Mandey, L. C. (2014). Karakteristik Mutu Mikrobiologis Ikan Pinekuhe Kabupaten Kepulauan Sangihe. Jurnal Ilmu dan Teknologi Pangan, 2(1), 38.
Palawe, J. F. P., Suwetja, K., \& Mandey, L. C. (2020). Karakteristik Mutu Kimia Ikan Asap Pinekuhe Kabupaten Kepulauan Sangihe. Jurnal FishtecH, 9(1), 13-20.

Palawe, J. F. P., Cahyono, E., \& Karimela, E. J. (2018). Uji Aktifitas Anti Mikroba Ekstrak Ethanol Daun Mangrove Api-Api (Avecennia Marina) Pada Total Mikroba san Staphylococcus Epidermidis Ikan Pinekuhe. Jurnal FishtecH, 7(2), 131-137

Pagoray, M. 2004. Pengaruh Konsentrasi dan Cara Pemberian Asap cair Terhadap Mutu Fillet Cakalang (Katsuwonus pelamis) Asap Skripsi, Fakultas Perikanan dan Ilmu Kelautan Universitas Sam Ratulangi. Manado.

Setiaji, B. 2006. Asap Cair (Liquid smoke) Sebagai Bahan Pengawet alami yang Aman Bagi Manusia. Pusat Pengolaan Terpadu. Yogyakarta.

Swastawati Fronthea, Bambang Cahyono dan Ima Wijayanti. 2017. Perubahan Karakteristik Kualitas Ikan Tongkol (Euthynnus Affinis) Dengan Metode Pengasapan Tradisional Dan Penerapan Asap Cair. Jurnal Info ISSN : 0852-1816. Volume 19, Nomor 2. Fakultas Perikanan dan Ilmu Kelautan, Universitas Diponegoro. Semarang.

Tirajoh, J. 1995. Pengaruh Jenis Bahan Bakar, Metode Pengasapan Dan Lama Penyimpanan Terhadap Mutu

Fillet Cucut (Carcharhinus Limbatus) Asap. Fakultas Perikanan Universitas Sam Ratulangi. Manado.

Varlet, Vincent., Carole Prost., Thierry Serot. 2007. Volatile Aldehydes in Smoked Fish: Analysis Methods, Occurrence and Mechanism of Formation. Food Chemistry 105: 1536-1556 